\title{
Pseudonocardia kongjuensis sp. nov., isolated from a gold mine cave
}

\author{
1 School of Biological \\ Sciences and Research \\ Center for Molecular \\ Microbiology, Seoul \\ National University, Seoul \\ 151-742, Republic of Korea \\ 2 Department of Plant \\ Pathology, University of \\ Minnesota, St Paul, \\ MN 55108, USA \\ 3 Lady Davis Institute, 3999 \\ Cote St Catherine Road, \\ Montreal, Quebec, Canada \\ H3T 1E2
}

\author{
Soon Dong Lee, ${ }^{1,2}$ Eun Suk Kim, ${ }^{1}$ Kyung-Lyum Min, ${ }^{1,3}$ Wha Young Lee, ${ }^{1}$ \\ Sa-Ouk Kang ${ }^{1}$ and Yung Chil Hah'
}

Author for correspondence: Yung Chil Hah. Tel: +82 2880 6700. Fax: +8228884911. e-mail: hahyungc@snu.ac.kr

\begin{abstract}
The taxonomic position of an isolate that was recovered from a gold mine cave near Kongju, Republic of Korea, was determined by $16 \mathrm{~S}$ rDNA sequence studies and chemotaxonomic characterization. Comparative studies of 16S rDNA sequences indicated that this organism was phylogenetically related to members of the genus Pseudonocardia, branching outside a cluster encompassing Pseudonocardia autotrophica and Pseudonocardia compacta. The affiliation to the genus was also supported by the cell chemistry, which was represented by a type IV cell wall, $\mathrm{MK}-8\left(\mathrm{H}_{4}\right)$ as the major menaquinone, a phospholipid type PIII pattern (phosphatidylcholine as a diagnostic phospholipid) and a DNA G+C content of $71 \mathrm{~mol} \%$. The fatty acid profile contained saturated, unsaturated and 10-methyl branched fatty acids, but tuberculostearic acid and hydroxy fatty acids were not present. The isolate differed from its phylogenetic neighbours in the presence of phosphatidylethanolamine, dodecanoate, 16-methylheptadecenoate and 16methylheptadecanoate and the absence of phosphatidylinositol mannoside and phosphatidylmethylethanolamine. The unique combination of physiological properties, the cellular fatty acid profile and DNA-DNA hybridization data indicates that this organism is readily differentiated from the type strains of all of the validly published species of the genus Pseudonocardia. The name Pseudonocardia kongjuensis sp. nov. is proposed

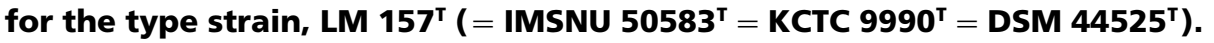

Keywords: Pseudonocardia kongjuensis sp. nov., soil bacteria, 16S rDNA sequence studies, chemotaxonomy

\section{INTRODUCTION}

The genus Pseudonocardia, proposed originally by Henssen (1957), was recently emended by Reichert et al. (1998) with the proposal of two new dimethyl disulfide-degrading species and currently contains 12 validly described species: Pseudonocardia alni, Pseudonocardia asaccharolytica, Pseudonocardia autotrophica, Pseudonocardia compacta, Pseudonocardia halophobica, Pseudonocardia hydrocarbonoxydans, Pseudonocardia nitrificans, Pseudonocardia petroleophila, Pseudonocardia saturnea, Pseudonocardia spinosa, Pseudonocardia sulfidoxydans and Pseudo-

The EMBL accession number for the $16 \mathrm{~S}$ rDNA sequence of strain LM $157^{\top}$ is AJ252833. nocardia thermophila. Phylogenetically, the genus forms a distinct lineage within the radiation of the family Pseudonocardiaceae (McVeigh et al., 1994; Warwick et al., 1994; Reichert et al., 1998) and has a following characteristics: vegetative and aerial mycelium with spore chains produced by acropetal budding or fragmentation, type IV cell wall, major menaquinone is MK-8 $\left(\mathrm{H}_{4}\right)$, DNA $\mathrm{G}+\mathrm{C}$ content of 68-79 mol \%, no mycolic acids and phospholipid type II or III pattern, according to the species. The interand intrageneric relationships of the genera Pseudonocardia and Actinobispora (Jiang et al., 1991) based on $16 \mathrm{~S}$ rDNA sequences were investigated in our recent study (Lee et al., 2000b). In this paper, we describe the characterization and classification of a soil isolate, LM $157^{\mathrm{T}}$, for which a new species is proposed, Pseudonocardia kongjuensis sp. nov. 


\section{METHODS}

Micro-organisms and culture conditions. Strain LM $157^{\mathrm{T}}$ was isolated from soil collected at a gold mine cave in Kongju, Korea, by the dilution plating method on tap water agar (Lee, 1996). To obtain cells, the organism were grown on trypticase soy broth (BBL) with shaking at $30{ }^{\circ} \mathrm{C}$ for $3 \mathrm{~d}$. For comparison, the following Pseudonocardia type strains were used: $P$. alni IFO $14491^{\mathrm{T}}\left(=\mathrm{IMSNU} 20049^{\mathrm{T}}\right), P$. autotrophica IFO $12743^{\mathrm{T}}\left(=\mathrm{IMSNU} 20050^{\mathrm{T}}\right)$ and $P$. compacta IFO $14343^{\mathrm{T}}\left(=\mathrm{IMSNU} 20111^{\mathrm{T}}\right)$.

For morphological observation, strain LM $157^{\mathrm{T}}$ was grown on yeast extract/malt extract agar (ISP 2 medium) for 1-2 weeks at $28^{\circ} \mathrm{C}$. Morphological, physiological and chemotaxonomic characteristics were determined as described previously (Lee et al., 2000a).

Phylogenetic analyses. The $16 \mathrm{~S}$ rDNA sequences of strain LM $157^{\mathrm{T}}$ and reference organisms were aligned using the CLUSTAL W program (Thompson et al., 1994) and a phylogenetic tree was constructed by the neighbour-joining method (Saito \& Nei, 1987) using the distance coefficient of Jukes \& Cantor (1969). Parsimony analysis was performed with the PAUP program for the Macintosh (Swofford, 1998). DNA base composition and the level of DNA-DNA relatedness between isolate LM $157^{\mathrm{T}}$ and reference organ- isms were determined by methods described previously (Lee et al., 2000c).

\section{RESULTS AND DISCUSSION}

The almost complete 16S rDNA sequence of strain LM $157^{\mathrm{T}}$ was compared with those of representatives of the family Pseudonocardiaceae and subsequently with those of species of the genera Pseudonocardia and Actinobispora. A total of 1441 unambiguous nucleotides present in all strains between positions 29 and 1152 (Escherichia coli numbering; Brosius et al., 1978) were used in construction of the final tree. Phylogenetic analysis using distance-matrix and maximum-parsimony methods resulted in trees showing similar topologies. A phylogenetic tree (Fig. 1) indicated that strain LM $157^{\mathrm{T}}$ formed a branch between the $P$. autotrophica-P. compacta cluster and the $P$. alni-Pseudonocardia sp. IMSNU 22071 cluster. This relationship was supported by a high bootstrap value $(99 \%)$. Strain LM $157^{\mathrm{T}}$ showed levels of $16 \mathrm{~S}$ rDNA sequence similarity ranging from $94 \cdot 0$ to $98.8 \%$ to members of the genera Pseudonocardia and Actinobispora. Of the Pseudonocardia species, P. autotrophica

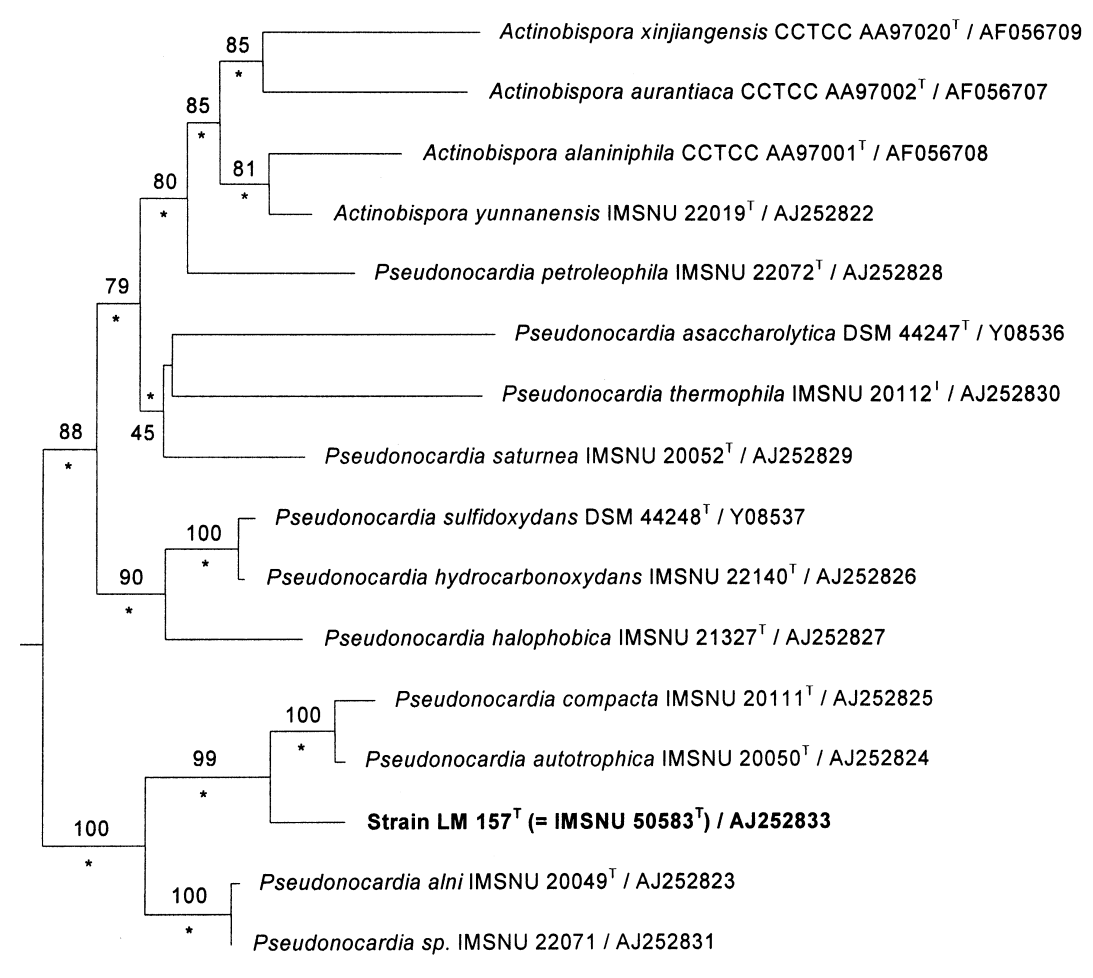

Fig. 1. Phylogenetic tree showing the position of strain LM $157^{\top}$ within the radiation of the genera Pseudonocardia and Actinobispora. The tree was constructed by the neighbour-joining method (Saito \& Nei, 1987) based on a comparison of 1441 unambiguous nucleotide positions. Saccharothrix violacea (Lee et al., 2000c) was used as an outgroup (not shown). Asterisks indicate branching nodes that were also recovered in the parsimony analysis. Numbers at the branching points are percentages of occurrence in 1000 bootstrapped trees (only values greater than $40 \%$ are indicated). Bar, 1 substitution per 100 nucleotides. 
Table 1. Phospholipid and fatty acid compositions of strain LM $157^{\top}$ and related taxa of the genus Pseudonocardia

All taxa shown contained diphosphatidylglycerol, phosphatidylcholine, phosphatidylglycerol and phosphatidylinositol. Abbreviations: PE, phosphatidylethanolamine; PIM, phosphatidylinositol mannoside; PME, phosphatidylmethylethanolamine; PL, unknown phospholipid(s); i, iso; ai, anteiso; 10Me, 10-methyl. Percentages of total fatty acid content are given; fatty acids present at less than $0.5 \%$ in all taxa are not shown. ND, Not detected.

\begin{tabular}{|c|c|c|c|c|}
\hline Component & Strain LM $157^{\mathrm{T}}$ & P. compacta IMSNU $20111^{\mathrm{T}}$ & P. autotrophica IMSNU $20050^{\mathrm{T}}$ & P. alni IMSNU 20049 \\
\hline \multicolumn{5}{|c|}{ Phospholipids } \\
\hline $\mathrm{PE}$ & + & + & - & + \\
\hline PIM & - & + & + & - \\
\hline PME & - & + & + & + \\
\hline PL & - & + & + & - \\
\hline \multicolumn{5}{|l|}{ Fatty acids } \\
\hline $\mathrm{C}_{12: 0}$ & $0 \cdot 6$ & ND & ND & ND \\
\hline $\mathrm{i}-\mathrm{C}_{14: 0}$ & ND & 1.9 & ND & ND \\
\hline $\mathrm{i}-\mathrm{C}_{15: 1}$ & ND & $\mathrm{ND}$ & ND & 0.6 \\
\hline $\mathrm{i}-\mathrm{C}_{15: 0}$ & $2 \cdot 4$ & $3 \cdot 6$ & $4 \cdot 3$ & $11 \cdot 2$ \\
\hline $\mathrm{C}_{15: 1}$ & $\mathrm{ND}$ & $5 \cdot 0$ & ND & $\mathrm{ND}$ \\
\hline $\mathrm{C}_{15: 0}$ & ND & $10 \cdot 0$ & ND & ND \\
\hline $\mathrm{i}-\mathrm{C}_{16: 1}$ & $6 \cdot 7$ & $4 \cdot 2$ & $10 \cdot 0$ & $18 \cdot 2$ \\
\hline $\mathrm{i}-\mathrm{C}_{16: 0}$ & $31 \cdot 4$ & $34 \cdot 5$ & $33 \cdot 5$ & $28 \cdot 0$ \\
\hline $\mathrm{C}_{16: 1}$ & $7 \cdot 4$ & $3 \cdot 8$ & $4 \cdot 4$ & $4 \cdot 9$ \\
\hline $\mathrm{C}_{16: 0}$ & $6 \cdot 0$ & $3 \cdot 0$ & $2 \cdot 0$ & $1 \cdot 0$ \\
\hline $\mathrm{i}-\mathrm{C}_{17: 1}$ & $4 \cdot 4$ & $\mathrm{ND}$ & $5 \cdot 5$ & $9 \cdot 7$ \\
\hline $10 \mathrm{Me}-\mathrm{C}_{16: 0}$ & $3 \cdot 6$ & $1 \cdot 1$ & $6 \cdot 1$ & $4 \cdot 2$ \\
\hline $\mathrm{i}-\mathrm{C}_{17: 0}$ & $6 \cdot 2$ & $1 \cdot 0$ & $7 \cdot 4$ & $6 \cdot 3$ \\
\hline $\mathrm{C}_{17: 1}$ & $13 \cdot 8$ & $19 \cdot 9$ & $10 \cdot 0$ & $12 \cdot 1$ \\
\hline $\mathrm{C}_{17: 0}$ & $0 \cdot 7$ & $4 \cdot 8$ & ND & ND \\
\hline $\mathrm{i}-\mathrm{C}_{18: 1}$ & $1 \cdot 7$ & $\mathrm{ND}$ & 0.6 & ND \\
\hline $10 \mathrm{Me}-\mathrm{C}_{17: 0}$ & $3 \cdot 8$ & $3 \cdot 8$ & $10 \cdot 0$ & $1 \cdot 6$ \\
\hline $\mathrm{i}-\mathrm{C}_{18: 0}$ & $0 \cdot 6$ & $\mathrm{ND}$ & $\mathrm{ND}$ & $\mathrm{ND}$ \\
\hline $\mathrm{C}_{18: 0}$ & $9 \cdot 6$ & $2 \cdot 6$ & $3 \cdot 3$ & $1 \cdot 8$ \\
\hline
\end{tabular}

$(98.8 \%)$ and $P$. compacta $(98 \cdot 5 \%)$ revealed the highest sequence similarity to strain LM $157^{\mathrm{T}}$.

16S rDNA sequence studies indicated that isolate LM $157^{\mathrm{T}}$ is related to members of the genera Pseudonocardia and Actinobispora (Fig. 1). We recently examined the inter- and intrageneric relationships of the genera Pseudonocardia and Actinobispora based on 16S rDNA sequence studies (Lee et al., 2000b). In our previous study, all of the validly named species of genus Pseudonocardia formed a coherent cluster with members of the genus Actinobispora, within the radiation of the family Pseudonocardiaceae. The type strains of both genera were intermixed and separated well from members of the other genera of the family Pseudonocardiaceae. This relationship was supported by a high bootstrap value of $100 \%$ and the presence of 16S rDNA signature nucleotides unique for both genera (Lee et al., 2000b). Our recent study showed that Actinobispora yunnanensis IMSNU $22019^{\mathrm{T}}$ possessed MK-8 $\left(\mathrm{H}_{4}\right)$ as a major menaquinone (Lee et al., $2000 \mathrm{~b}$ ), which was not consistent with the results of Jiang et al. (1991) and $\mathrm{Xu}$ et al. (1999). Thus, phylogenetic evidence and chemical data, with the exception of phospholipid composition, suggest the unification of the two genera.

The affiliation of strain LM $157^{\mathrm{T}}$ to the genus Pseudonocardia was confirmed by chemotaxonomic data. Strain LM $157^{\mathrm{T}}$ has chemotaxonomic properties consistent with those of the genus Pseudonocardia (Reichert et al., 1998) as follows: the presence of mesodiaminopimelic acid, arabinose and galactose (type IV cell wall; Lechevalier \& Lechevalier, 1970), the acetyl type of murein, no mycolic acid, $\mathrm{MK}-8\left(\mathrm{H}_{4}\right)$ as the major menaquinone and phospholipid type PIII pattern (phosphatidylcholine as a diagnostic phospholipid).

Strain LM $157^{\mathrm{T}}$ is differentiated from related Pseudonocardia species by the presence and/or the absence of phosphatidylinositol mannoside, phosphatidylethanolamine, phosphatidylmethylethanolamine and an unknown phospholipid(s) (Table 1). Since the results of fatty acid analyses can differ to some extent according to the laboratory and the methods used, the fatty acid profiles of the isolate and the type strains of related taxa were determined 
Table 2. Characteristics that differentiate strain LM $157^{\top}$ from reference Pseudonocardia strains

All taxa were negative for production of acid from D-xylitol.

\begin{tabular}{|c|c|c|c|c|}
\hline Characteristic & Strain LM $157^{\mathrm{T}}$ & P. compacta IMSNU 20111 & P. autotrophica IMSNU 20050 & P. alni IMSNU $20049^{\mathrm{T}}$ \\
\hline \multicolumn{5}{|l|}{ Acid produced from: } \\
\hline L-Arabinose & - & - & + & + \\
\hline D-Cellobiose & + & + & + & - \\
\hline D-Galactose & + & - & + & + \\
\hline Maltose & + & - & + & + \\
\hline D-Mannose & + & - & + & - \\
\hline D-Melezitose & + & - & + & + \\
\hline Methyl $\alpha$-D-glucoside & - & - & + & - \\
\hline Salicin & - & - & - & + \\
\hline Sucrose & + & - & + & + \\
\hline D-Trehalose & + & - & + & + \\
\hline D-Xylose & + & - & + & + \\
\hline Adonitol & + & - & + & + \\
\hline meso-Erythritol & - & - & - & + \\
\hline meso-Inositol & + & - & + & - \\
\hline D-Mannitol & + & + & + & - \\
\hline 1,2-Propanediol & - & - & + & + \\
\hline D-Sorbitol & - & - & + & + \\
\hline $\mathrm{H}_{2} \mathrm{~S}$ production & + & - & + & + \\
\hline Urease activity & + & - & + & + \\
\hline \multicolumn{5}{|l|}{ Decomposition of: } \\
\hline Hypoxanthine & + & - & - & + \\
\hline Tyrosine & + & - & - & + \\
\hline Xanthine & - & - & - & + \\
\hline \multicolumn{5}{|l|}{ Hydrolysis of: } \\
\hline Casein & + & - & - & - \\
\hline Gelatin & - & - & - & + \\
\hline Starch & - & - & - & + \\
\hline \multicolumn{5}{|l|}{ Growth at/on: } \\
\hline $4{ }^{\circ} \mathrm{C}$ & + & + & - & - \\
\hline $37^{\circ} \mathrm{C}$ & + & - & + & + \\
\hline $7 \% \mathrm{NaCl}$ & + & - & + & + \\
\hline
\end{tabular}

under standardized conditions (Table 2). All test strains had saturated, unsaturated and 10-methyl branched fatty acids but did not possess tuberculostearic acid or hydroxy fatty acids. However, strain LM $157^{\mathrm{T}}$ differed from the Pseudonocardia reference strains in the amounts of hexadecanoic $\left(\mathrm{C}_{16: 0}\right)$, hexadecenoic $\left(\mathrm{C}_{16: 1}\right)$ and octadecanoic $\left(\mathrm{C}_{18: 0}\right)$ acids and by the presence of small amounts of dodecanoic $\left(\mathrm{C}_{12: 0}\right)$, 16-methylheptadecanoic (i- $\left.\mathrm{C}_{18: 0}\right)$ and 16methylheptadecenoic (i- $\left.\mathrm{C}_{18: 1}\right)$ acids.

The physiology of the new isolate was compared with that of reference strains for a total of 47 characters. Most of the physiological properties of the reference strains were confirmed in this study, in agreement with those described previously (Reichert et al., 1998). However, P. alni IMSNU $20049^{\mathrm{T}}$ did not produce acid from methyl $\alpha$-D-glucoside or D-mannitol and $P$. autotrophica IMSNU $20050^{\mathrm{T}}$ did not produce acid from meso-erythritol, in disagreement with previous results (Reichert et al., 1998). All of the reference strains produced acid from D-glucose, D-fructose and glycerol, whereas isolate LM $157^{\mathrm{T}}$ showed a weak positive reaction in acid production from $\mathrm{D}$-fructose and glycerol. None of the test strains produced acid from D-lactose, melibiose, methyl $\alpha$-D-mannoside, Draffinose, L-rhamnose, L-sorbose, 2,3-butanediol or dulcitol. Isolate LM $157^{\mathrm{T}}$ has a morphology typical of the genus Pseudonocardia, in that aerial mycelium is fragmented into non-motile, rod-shaped spores (Fig. 2). The spore surface was smooth. No specific structures, such as sporangia, synnemata or sclerotia, were observed. Isolate LM $157^{\mathrm{T}}$ grew well on all of the media used. Substrate mycelium was well-developed and yellowish-brown. No distinctive pigment was produced.

Strain LM $157^{\mathrm{T}}$ differs physiologically from $P$. autotrophica IMSNU $20050^{T}$ in acid production from Larabinose, methyl $\alpha$-D-glucoside, 1,2-propanediol and $\mathrm{D}$-sorbitol, in the decomposition of hypoxanthine and tyrosine and in the hydrolysis of casein (Table 2). The 


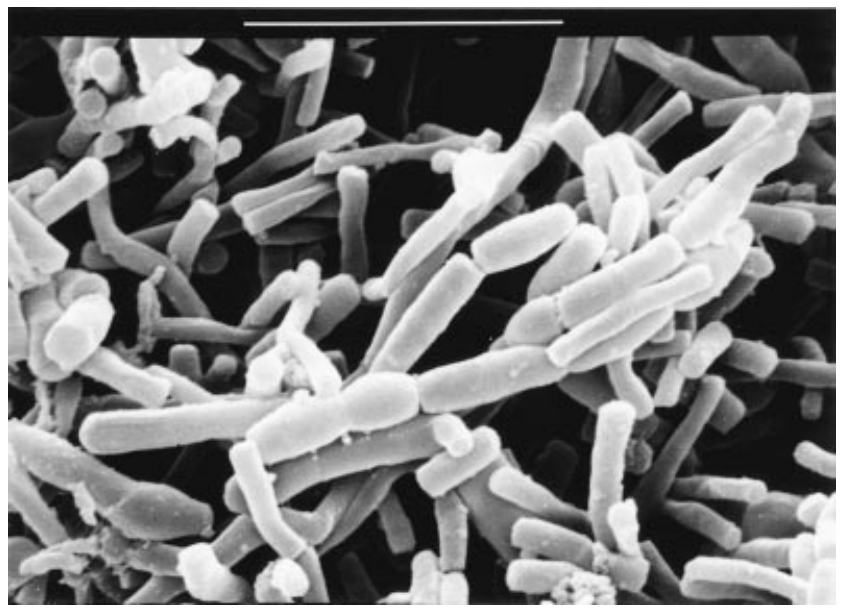

Fig. 2. Scanning electron micrograph of strain $L M 157^{\top}$ grown on yeast extract/malt extract agar (ISP medium 2). Bar, $5 \mu \mathrm{m}$.

isolate is readily distinguished from $P$. compacta IMSNU $2011^{\mathrm{T}}$ by most of the physiological characters tested (Table 2). DNA-DNA hybridization studies showed that the isolate exhibited low levels of DNA relatedness to its phylogenetic neighbours $P$. autotrophica $(32 \%)$ and $P$. compacta $(14 \%)$. The DNA $\mathrm{G}+\mathrm{C}$ content of isolate $\mathrm{LM} 157^{\mathrm{T}}$ was $71 \mathrm{~mol} \%$.

Despite high phylogenetic similarity, $P$. compacta IMSNU $20111^{T}$ can be readily differentiated from $P$. autotrophica IMSNU $20050^{\mathrm{T}}$ by its fatty acid profile, the presence of phosphatidylethanolamine and its physiological properties (Tables 1 and 2). Pseudonocardia sp. IMSNU 22071 (= DSM 44061), which had previously been described as 'Streptomyces nitrificans' (Schatz et al., 1954), shows the same result as $P$. alni IMSNU $20049^{\mathrm{T}}$ for phospholipid composition and all of the physiological tests except for acid production from D-mannose, D-trehalose and Dxylitol. These facts, together with the high level of $16 \mathrm{~S}$ rDNA sequence similarity $(99.9 \%)$, indicate that Pseudonocardia sp. IMSNU 22071 (= DSM 44061) is a strain of $P$. alni.

The unique combination of phenotypic and genotypic properties support the conclusion that isolate LM $157^{\mathrm{T}}$ merits species status in the genus Pseudonocardia, and the name Pseudonocardia kongjuensis sp. nov. is proposed.

\section{Description of Pseudonocardia kongjuensis sp. nov.}

Pseudonocardia kongjuensis (kong.ju.en'sis. N. L. adj. kongjuensis of Kongju, Republic of Korea).

Aerobic, Gram-positive, non-acid-alcohol-fast. Forms a white aerial mycelium that fragments into rodshaped spores. The spore surface is smooth. Substrate mycelium is abundant and yellowish-brown. Growth occurs between 4 and $37^{\circ} \mathrm{C}$. Catalase-positive. Ureasepositive. $\mathrm{H}_{2} \mathrm{~S}$ is produced. Acid is produced from
D-cellobiose, D-galactose, D-glucose, maltose, D-mannose, D-melezitose, sucrose, D-trehalose, D-xylose, adonitol, meso-inositol and D-mannitol. No acid production from L-arabinose, D-lactose, melibiose, methyl $\alpha$-D-glucoside, methyl $\alpha$-D-mannoside, D-raffinose, Lrhamnose, salicin, L-sorbose, 2,3-butanediol, dulcitol, meso-erythritol, 1,2-propanediol, D-sorbitol or Dxylitol. Weak acid production from D-fructose and glycerol. Casein is hydrolysed. Gelatin and starch are not hydrolysed. Hypoxanthine and tyrosine are decomposed. Xanthine is not decomposed. Growth occurs on $7 \% \mathrm{NaCl}$. Type IV cell wall (mesodiaminopimelic acid, arabinose and galactose in the cell wall). The acyl type of muramic acid is acetyl. The major menaquinone is MK-8( $\left.\mathrm{H}_{4}\right)$. The phospholipid profile contains phosphatidylcholine, phosphatidylethanolamine, diphosphatidylglycerol, phosphatidylglycerol and phosphatidylinositol (phospholipid type PIII pattern). The fatty acid profile contains saturated, unsaturated and 10-methyl branched fatty acids but tuberculostearic acid and hydroxy fatty acids are not present. Small amounts of dodecanoate, 16-methylheptadecenoate and 16-methylheptadecanoate are also present. The $\mathrm{G}+\mathrm{C}$ content of the DNA is $71 \mathrm{~mol} \%$.

Isolated from a gold mine cave in Kongju, Republic of Korea. The type strain is strain LM $157^{\mathrm{T}}$ (= IMSNU $50583^{\mathrm{T}}=$ KCTC $\left.9990^{\mathrm{T}}=\operatorname{DSM} 44525^{\mathrm{T}}\right)$.

\section{ACKNOWLEDGEMENTS}

This work was supported by the Brain Korea 21 Project for the School of Biological Sciences, Seoul National University.

\section{REFERENCES}

Brosius, J., Palmer, M. L., Kennedy, P. J. \& Noller, H. F. (1978). Complete nucleotide sequence of a $16 \mathrm{~S}$ ribosomal RNA gene from Escherichia coli. Proc Natl Acad Sci U S A 75, 4801-4805.

Henssen, A. (1957). Beitrage zur Morphologie und Systematik der thermophilen Actinomyceten. Arch Mikrobiol 26, 373-414.

Jiang, C., Xu, L., Yang, Y.-R., Guo, G.-Y., Ma, J. \& Liu, Y. (1991). Actinobispora, a new genus of the order Actinomycetales. Int $J$ Syst Bacteriol 41, 526-528.

Jukes, T. H. \& Cantor, C. R. (1969). Evolution of protein molecules. In Mammalian Protein Metabolism, pp. 21-132. Edited by H. N. Munro. New York: Academic Press.

Lechevalier, M. P. \& Lechevalier, H. (1970). Chemical composition as a criterion in the classification of aerobic actinomycetes. Int J Syst Bacteriol 20, 435-443.

Lee, S. D. (1996). Classification of novel actinomycetes from gold mine cave in Kongju, Korea. PhD thesis, Seoul National University, Seoul, Korea.

Lee, S. D., Kang, S.-O. \& Hah, Y. C. (2000a). Hongia gen. nov., a new genus of the order Actinomycetales. Int J Syst Evol Microbiol 50, 191-199.

Lee, S. D., Kim, E. S. \& Hah, Y. C. (2000b). Phylogenetic analysis of the genera Pseudonocardia and Actinobispora based on 16S ribosomal DNA sequences. FEMS Microbiol Lett 182, 125-129.

Lee, S. D., Kim, E. S., Roe, J.-H., Kim, J., Kang, S.-O. \& Hah, Y. C. (2000c). Saccharothrix violacea sp. nov., isolated from a gold 
mine cave, and Saccharothrix albidocapillata comb. nov. Int $J$ Syst Evol Microbiol 50, 1315-1323.

McVeigh, H. P., Munro, J. \& Embley, T. M. (1994). The phylogenetic position of Pseudoamycolata halophobica (Akimov et al. 1989) and a proposal to reclassify it as Pseudonocardia halophobica. Int J Syst Bacteriol 44, 300-302.

Reichert, K., Lipski, A., Pradella, S., Stackebrandt, E. \& Altendorf, K. (1998). Pseudonocardia asaccharolytica sp. nov. and Pseudonocardia sulfidoxydans sp. nov., two new dimethyl disulfidedegrading actinomycetes and emended description of the genus Pseudonocardia. Int J Syst Bacteriol 48, 441-449.

Saitou, N. \& Nei, M. (1987). The neighbor-joining method: a new method for reconstructing phylogenetic trees. Mol Biol Evol 4, 406-425.

Schatz, A., Isenberg, H. D., Angrist, A. \& Schatz, V. (1954). Microbial metabolism of carbamates. I. Isolation of Streptomyces nitrificans spec. nov., and other organisms which grow on urethane. $J$ Bacteriol $68,1-4$.
Swofford, D. (1998). PAUP*: phylogenetic analysis using parsimony (*and other methods), version 4.0. Sunderland, MA: Sinauer Associates.

Thompson, J. D., Higgins, D. G. \& Gibson, T. J. (1994). CLUSTAL $\mathrm{W}$ : improving the sensitivity of progressive multiple sequence alignment through sequence weighing, position-specific gap penalties and weight matrix choice. Nucleic Acids Res 22, 4673-4680.

Warwick, S., Bowen, T., McVeigh, H. \& Embley, T. M. (1994). A phylogenetic analysis of the family Pseudonocardiaceae and the genera Actinokineospora and Saccharothrix with 16S rRNA sequences and a proposal to combine the genera Amycolata and Pseudonocardia in an emended genus Pseudonocardia. Int J Syst Bacteriol 44, 293-299.

Xu, L.-H., Jin, X., Mao, P.-H., Lu, Z.-F., Cui, X.-L. \& Jiang, C.-L. (1999). Three new species of the genus Actinobispora of the family Pseudonocardiaceae, Actinobispora alaniniphila sp. nov., Actinobispora aurantiaca sp. nov. and Actinobispora xinjiangensis sp. nov. Int J Syst Bacteriol 49, 881-886. 